\title{
Practical Aspects Regarding the Histopathological Diagnosis of Early Mycosis Fungoides
}

\author{
T. TEBEICĂ ${ }^{1}$, R. ANDREI ${ }^{2}$, SABINA ZURAC $^{2,3}$, FLORICA STĂNICEANU ${ }^{2,3}$ \\ 1"Dr Leventer" Centre, Department of Histopathology, Bucharest \\ "Carol Davila" University of Medicine and Pharmacy, Bucharest \\ 3“"Colentina" University Hospital, Department of Pathology, Bucharest
}

\begin{abstract}
Mycosis fungoides is the most common primary T-cell lymphoma of skin. The disease has a protean clinical and histological presentation in its early patch and plaque stages, when distinction from mimicking inflammatory dermatoses is difficult. Since no single criterion is specific enough, a reliable diagnosis in early stages requires integration of clinical, histopathological and molecular findings. In skin biopsies, the most helpful histologic features are the detection of atypical lymphocytes in the epidermis with minimal epidermal changes, basal alignment of lymphocytes along dermal-epidermal junction and formation of Pautrier microabscesses. An aberrant immunophenotype of $\mathrm{T}$ cells and molecular detection of a clonal T-cell population are factors that could allow a more specific diagnosis. This work recapitulates and discusses these features from a practical perspective.
\end{abstract}

Key words: mycosis fungoides, epidermotropism, Pautrier microabscesses, parapsoriasis.

\section{DISEASE OVERVIEW}

Mycosis fungoides (MF) represents approximately $40 \%$ of all cutaneous lymphomas, being the most common primary $\mathrm{T}$-cell lymphoma of skin [1]. The disease manifests in a slowly progressive fashion, with patches and infiltrated plaques in the early stages, and skin tumors with eventual extracutaneous involvement in advanced disease. It occurs twice as often in men as in women and usually affects adults with a median age between 55 and 60 years, but cases in children have been documented as well [2].

The putative cell of origin of this lymphoma is considered to be a skin-homing lymphocyte, the resident memory $\mathrm{CD} 4+\mathrm{CD} 45 \mathrm{RO}+\mathrm{T}$ helper lymphocyte [3]. Neoplastic cells commonly comprise just a small fraction of the lymphoid infiltrate in early stages, when they can even be completely absent [4]. Therefore, the histologic picture and even the clinical presentation often overlap with those of other T-cell mediated inflammatory dermatoses. The predominance of reactive lymphocytes in these stages is probably the main reason of frequently encountered inconclusive biopsy results, lack of specific criteria and low concordance rates among pathologists [5]. Besides diagnosing MF at an early stage, even more difficult is to predict which patients are prone to develop advanced disease.

\section{CLINICAL PRESENTATION}

The clinical findings of early MF are not entirely specific. The lesions often mimick diverse inflammatory dermatoses, but they do not improve with, or recur after conventional treatments. In the early stages, patients present with intractable, illdefined, variably sized erythematous patches. The lesions are usually non-pruritic and possibly overlied by a thin, silvery scale. Poikylodermatous areas and/or more indurated, thicker, palpable lesions can be encountered in the plaque stage. Mainly affected are sun protected areas, such as the thighs and the lower part of the trunk, although any skin-site may be involved in advanced stages, including the face and scalp [6]. Multiple lesions are usually existent in $\mathrm{MF}$ at the initial presentation, but localized forms of the disease such as pagetoid reticulosis, also known as Woringer-Kolopp disease [7], and solitary skin lesions with features of classic MF have also been described [8]. 


\section{HISTOPATHOLOGY}

The microscopic changes seen in biopsies taken from clinically subtle skin lesions of early MF without acquired vertical growth are often discrete and can be challenging [6]. Since there are many inflammatory conditions that histologically mimic this cutaneous lymphoma, a definitive histopathologic diagnosis should not be attempted without a detailed knowledge of the clinical picture. Often, the diagnosis can be made with sufficient certainty only after clinical-pathological correlations and multiple biopsy assessments in the course of the disease. Algorithms for establishing an objective diagnosis of mycosis fungoides in the early phase have been proposed in several papers $[6,8-11]$, but they have not been included in the WHO classification so far [12]. This fact makes it clear that the early diagnosis of this disease is still an area of debate, not easy to integrate into simple algorithms.

The histopathologic picture of early MF is characterized by infiltrates of small to mediumsized lymphoid cells in the papillary and superficial reticular dermis, with individual lymphocytes migrating among epidermal keratinocytes, feature described as epidermotropism, the hallmark that portrays this lymphoma. These infiltrates usually include numerous reactive, non-neoplastic lymphocytes and histiocytes, distributed in a perivascular and interstitial or band-like manner and associated with slight fibrous thickening of the papillary dermis. Under the umbrella of the term epidermo- tropism various morphological aspects have been described $[4,9]$ : single intraepidermal cells with no tendency to coalesce, linearly arranged single cells along the basal epidermal layer, pagetoid spread of lymphocytes into the epidermis, tiny collections of three to four lymphocytes, and large intraepidermal clusters of atypical lymhoid cells referred to as Pautrier microabscesses.

An important finding in early MF is the basal alignment of lymphoid cells [13] along several contiguous rete ridges on the epidermal side of the dermal-epidermal junction in close apposition to basal kerationcytes (Figure 1). This finding was reported by different investigators as being present in $23 \%$ to $79 \%$ of biopsies taken in the patch/ plaque stage of MF $[4,9,14]$. Even more specific, but unfortunately less sensitive indicator of MF (4.2-45.8\% in variate studies) is the presence of Pautrier microabscesses [4, 9]. They represent intraepidermal clusters of four or more atypical $\mathrm{T}$ cells with no significant changes in the surrounding keratinocytes (Figure 2).

Cytological atypia in the form of slightly larger intraepidermal lymphocytes with convoluted or cerebriform and more hyperchromatic nuclei than the normal lymphocytes (Figure 3), narrow cytoplasm and a halo formation around the nucleus, is considered to be one of the most important histologic features for $\operatorname{MF}[9,15]$. As a consequence, cytological atypia was assigned a pivotal role in different diagnostic algorithms for early $\mathrm{MF}$ attempted so far $[6,8-11]$.

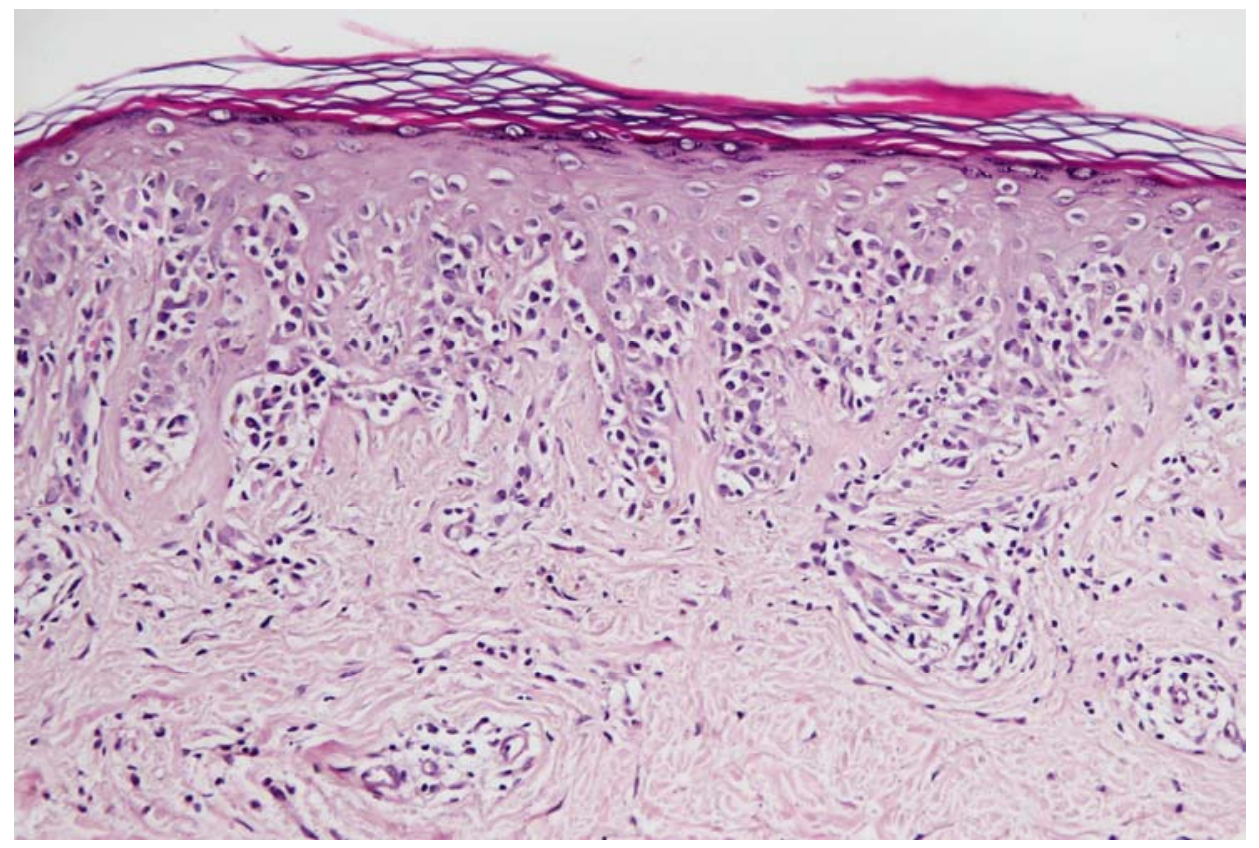

Figure 1. Alignment of mycosis cells along basal layer of the epidermis $(\mathrm{HE} \times 100)$. 


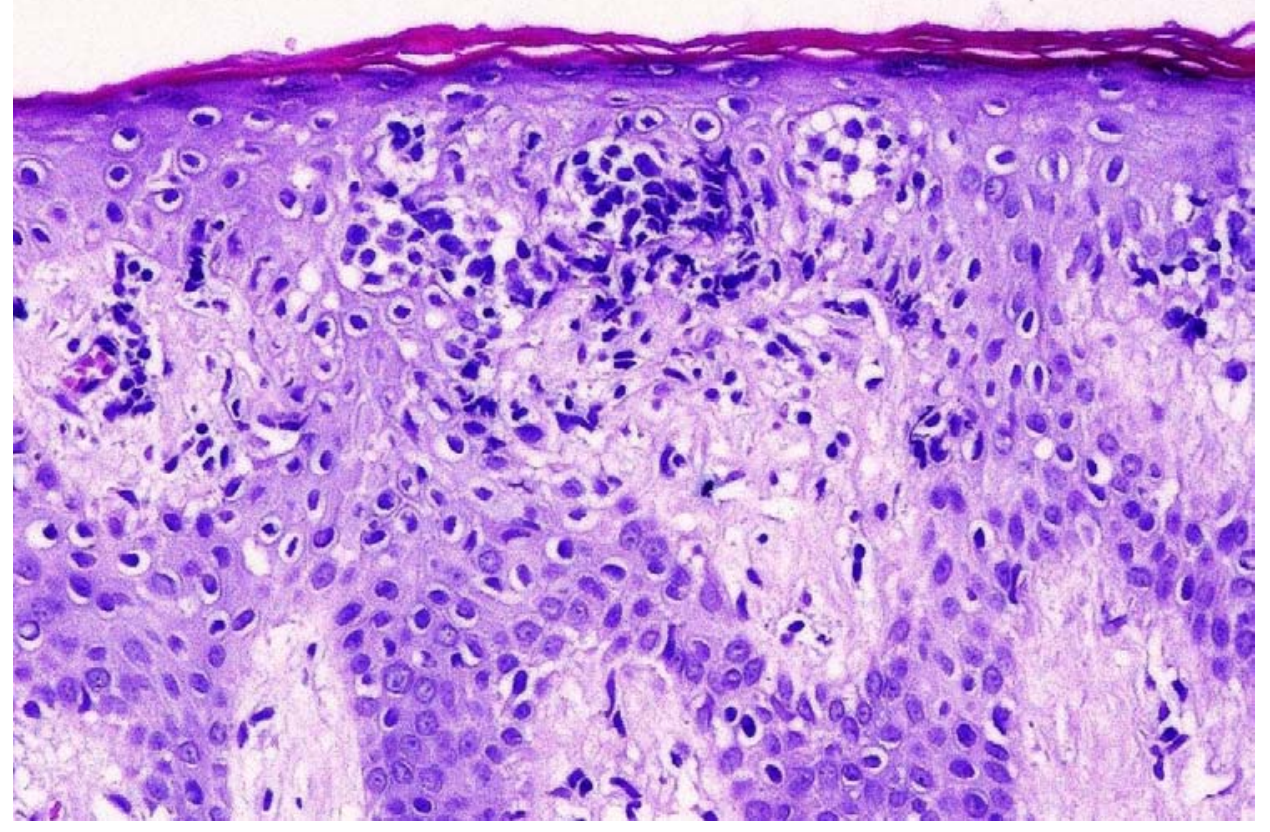

Figure 2. Intraepidermal collections of atypical lymphocytes representing Pautrier microabscesses (HE $\times 200)$.

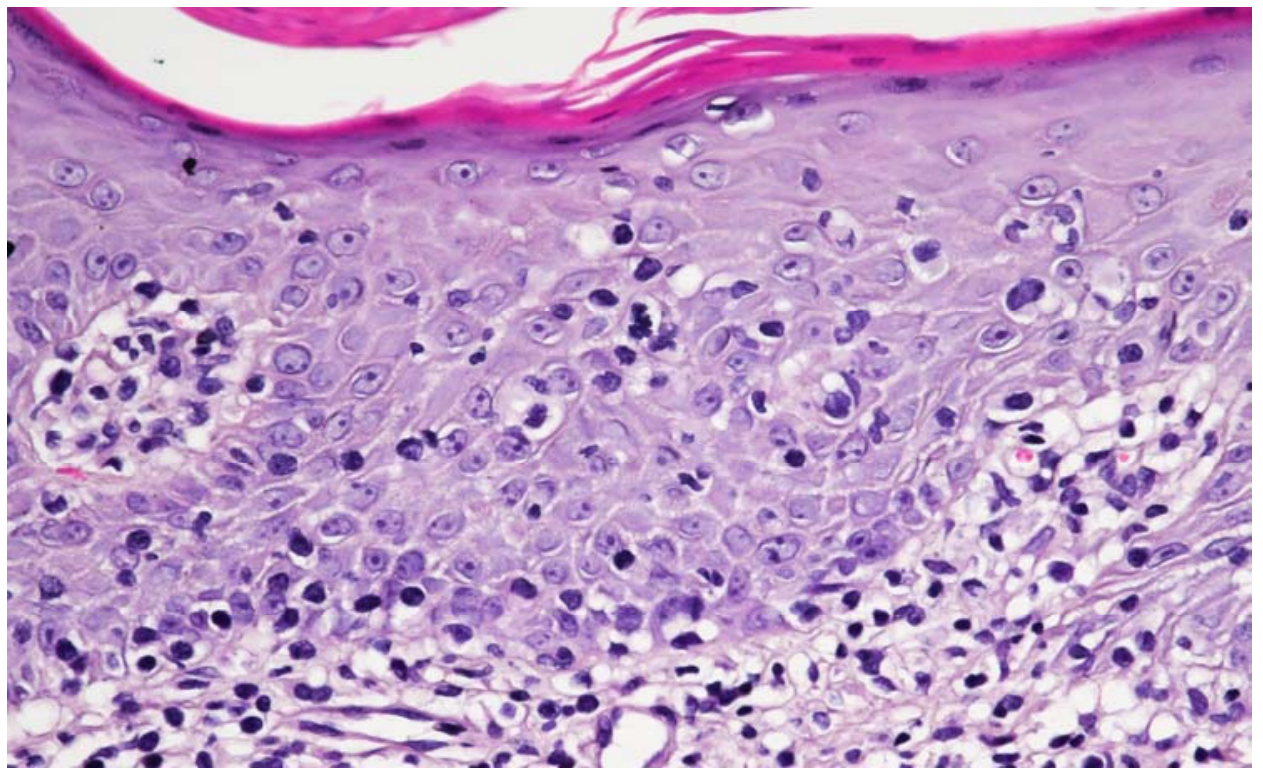

Figure 3. Intraepidermal lymphocytes with cerebriform nucleus $(\mathrm{HE} \times 400)$.

PRACTICAL ASPECTS

An infiltrate of epidermotropic lymphoid cells, usually considered characteristic for MF, is not entirely specific to this disease, being also observed in many inflammatory dermatoses. Conditions in which epidermotropism might be a microscopic feature include pityriasis lichenoides, pityriasis rosea, lichenoid dermatoses, drug eruptions, lichen sclerosus, inflammatory vitiligo, actinic reticuloid and reactive erythroderma among others [16]. These diseases, however, can be differentiated on clinical grounds and using other disease-specific histological features.

An important criterion for MF is the presence of epidermotropism without concomitant epidermal changes. While in MF there is often slight hyperkeratosis, usually in the form of elongated mounds of parakeratosis or scale-crusts, other findings such as marked spongiosis or a true lichenoid interface dermatitis pattern of inflammation with apoptotic keratinocytes, vacuolization of epidermal junction and saw-tooth apperarance of rete ridges are rather rare [16]. Hyperplastic epidermal changes pictured 
by prominent acanthosis and hyperkeratosis are not typical for MF and should make one consider the possibility of psoriasis vulgaris or pityriasis rubra pilaris. When extravasation of erythrocytes is encountered, the possibility of pityriasis rosea or pityriasis lichenoides needs to be considered. Another helpful clue to question a diagnosis of MF in early stages is the presence of large numbers of eosinophils in the infiltrate, feature considered rather an indicatior of inflammatory dermatitis [17].

Basal alignment of $\mathrm{T}$ cells occurs very rarely in inflammatory diseases in which autoreactive $\mathrm{T}$ cells attack basal keratinocytes or melanocytes, some examples being vitiligo and lichen sclerosus and atrophicus [16, 18]. The demarcation of these diseases is usually possible if the histological criteria are evaluated in the context of the clinical presentation. As simulators of Pautrier microabscesses, small groups of CD1a-positive intraepidermal Langerhans cells forming pseudopautrier microabscesses have been described in contact dermatitis [19]. They are collections of nonlymphoid mononuclear cells with histiocytic cytology and should not be confused with real Pautrier microabscesses.
Interestingly, the epidermotropism of mycosis fungoides might completely vanish after treatment with corticosteriods and it is also lost in the tumor stage of the disease, probably due to loss of surface molecules that bind neoplastic cells to keratinocytes [6].

\section{IMMUNOPHENOTYPE}

The typical lesion of MF shows an immunophenotype of mature T-helper cells [3], with expression of CD3 and CD4 and absence of CD8 (Figure 4). Sometimes, an aberrant T cell immunophenotype can be seen in early $\mathrm{MF}$, meaning that there is a loss of surface markers that are normally expressed in $\mathrm{T}$ cells under physiological conditions, such as CD2, CD5, and the $\beta$-chain of the T cell receptor $(\beta \mathrm{F} 1)$. There might even be an obvious attenuation or reduction of CD3 expression in epidermotropic tumor cells in comparison to the intradermal reactive T-cells [20]. It should be kept in mind that the loss of CD7 expression is less specific, as it is also frequently observed in inflammatory dermatoses [21].

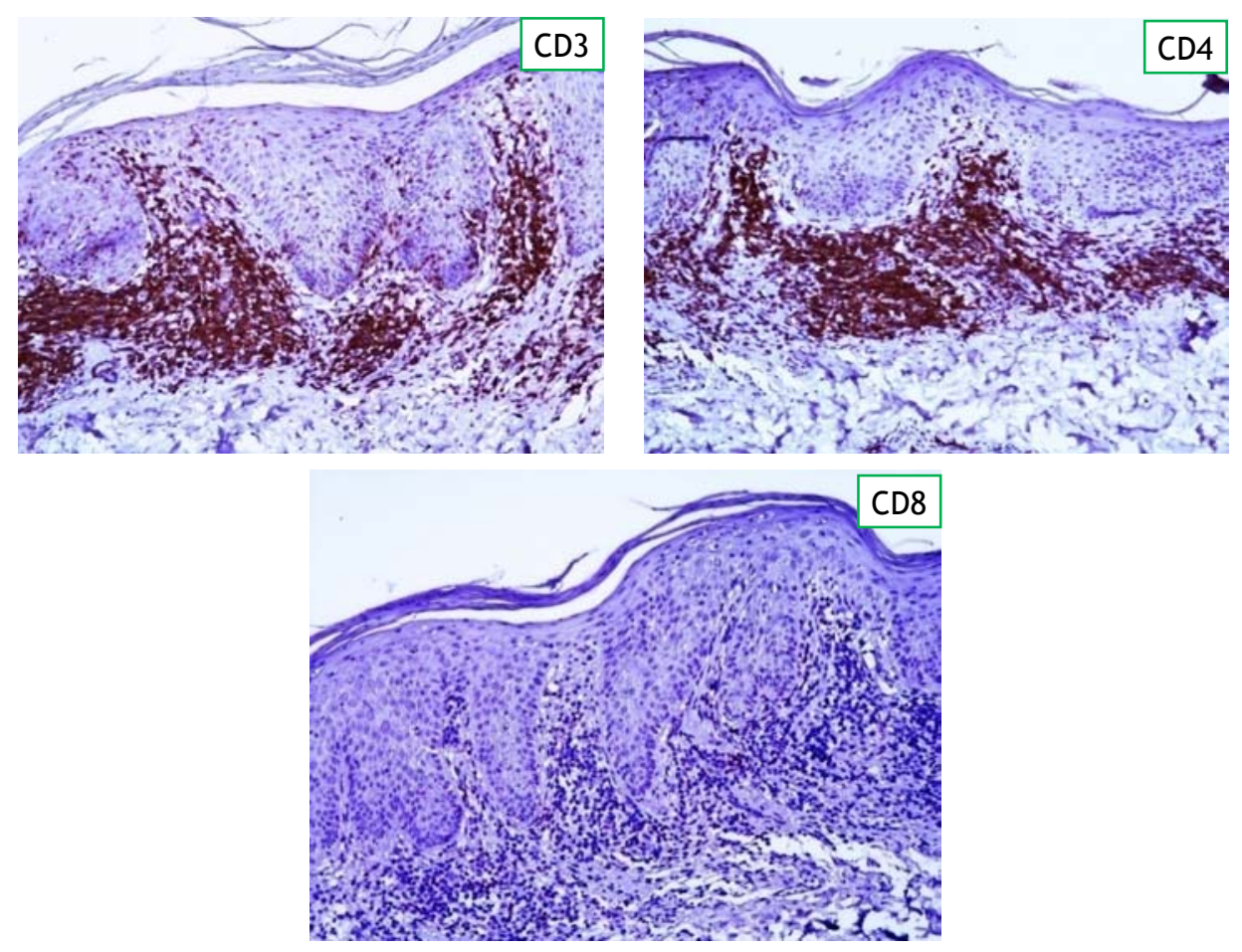

Figure 4. Immunophenotype of mycosis fungoides infiltrates: CD3+, CD4+, CD8- $(\mathrm{HE} \times 100)$.

\section{PRACTICAL ASPECTS}

When staining for $\mathrm{CD} 3$, the distribution of $\mathrm{T}$ cells can be more easily assessed. This way, the extent of epidermotropism, presence of Pautrier abscesses and basal alignment are readily highlighted. From a practical point of view, focusing on the assessment of the intraepidermal lymphocytes is recommendable, mainly because inside the intradermal infiltrate the reactive $\mathrm{T}$ cells strongly 
overlap with the potentially neoplastic population. At the level of epidermotropic lymphoid cells, any eventual deficiency of pan-T-cell antigens is easier to detect.

Staining biopsy sections with $\mathrm{CD} 8$ as a marker for cytotoxic T-cells and CD4 as a marker for T-helper cells allows an estimation of the ratio of T-cell populations to one another. Inflammatory dermatoses always make a mixture of CD4 and CD8-positive $\mathrm{T}$ cells, with a CD4+ to CD8+ ratio of about 3-4:1 [22]. Therefore, a very small number of CD8-positive T cells or a complete absence of CD8 expression in the intraepidermal or dermal $\mathrm{T}$ cells may be an important diagnostic sign for MF.

In rare instances, MF tumor cells are CD8positive. In these cases, however, a strongly reversed ratio in favor of CD8 is noticed [12]. If intraepithelial neoplastic T-cell infiltrates are CD4negative, the differential diagnosis should include the possibility of a rare but significantly more aggressive cutaneous T-cell lymphoma, especially CD8-positive cytotoxic T-cell aggressive epidermotropic lymphoma and the $\gamma-\delta$-T cell lymphoma [7]. Because an otherwise typical MF is occasionally capable of expressing CD8 or other cytotoxic markers, the differential diagnosis should never be done by immunophenotyping alone, but always in conjunction with the clinical scenario $[7,23]$.

Inside the infiltrate of MF, B lymphocytes are usually absent or detected just occasionally. As expected, evidence of increased CD20-positive $\mathrm{B}$ cells tends to favor an inflammatory dermatosis. When B-cells are strikingly predominant or in sheet-like distribution, cutaneous B-cell lymphoma or B-cell pseudolymphoma should be considered.

\section{MOLECULAR DIAGNOSIS}

Besides the histological and immunophenotypical characterization of cutaneous T-cell populations, molecular tests for clonality using T-cell receptor gene probes by PCR might be helpful in everyday clinical practice, but only if there are appropriate clinical and/or histopathological grounds for suspicion of MF. The detection of a clonal T-cell population is just one of several steps in the diagnosis of MF and not diagnostic per se. There are studies describing the presence of a clonal T-cell population identified by sensitive PCR techniques in specimens that do not show histopathologic features of MF [24, 25]. The diagnostic accuracy of the clonality studies increases when an identical clone is detected in two biopsies from different anatomic locations or in skin samples taken at various points in time. Of course, the PCR investigation has to be done under standardized conditions and with appropriate quality controls [26]. Interpretation of the clonality analysis requires relevant experience, including knowledge of the methodological and diagnostic pitfalls in the skin as an organ with a physiologically restricted $\mathrm{T}$ cell repertoire.

\section{PRACTICAL ASPECTS}

A negative clonality test does not exclude an initial diagnosis of MF and can be explained in various ways. If the neoplastic $\mathrm{T}$ cells are in minority and joined by a prominent reactive infiltrate, the neoplastic clone cannot step out of the polyclonal background [27]. It must also be borne in mind that the PCR primers cannot be tapped and amplify all possible T-cell receptor gene rearrangements. Depending on the stage of the disease, in paraffin-embedded tissue clonal T-cell populations are detected in only $50-90 \%$ of mycosis fungoides cases $[23,28]$. False-positive results, i.e. the detection of clonal $\mathrm{T}$-cell population in reactive inflammatory lesions, can be seen according to the literature in up to $17 \%$ reactive skin lesions [28].

\section{RELATIONSHIP TO PARAPSORIASIS}

Among some well defined inflammatory dermatoses, such as different eczematous reactions, dermatoses with a lichenoid pattern of inflammation, pityriasis lichenoides and drug reactions [16], the main condition that needs to be differentiated from MF and poses real diagnostic and prognostic dilemmas to dermatologists and pathologists when working up early MF is the so-called parapsoriasis en plaque, entity whose clinical and histomorphological demarcation is not well understood. Clinically, both parapsoriasis and early MF present with intractable, usually long lasting, slightly scaly and plaque-like lesions [29]. But parapsoriasis is defined by some authors as a reactive inflammatory disease different from mycosis fungoides, whereas others understand parapsoriasis as an initial phase of mycosis fungoides. Transition between the histological picture of both diseases has been clearly described in the literature [30-33]. This is in accordance with the theory which suggests an existence of a biologic grey zone between nonneoplastic inflammatory dermatoses and MF [34]. 
In practice, some authors use the term parapsoriasis exclusively for a skin disease in which there are so far no reliable criteria of manifest cutaneous lymphoma, i.e. clonality, aberrant immunophenotype, Pautrier microabscesses, identifiable neoplastic infiltrates [35]. The majority of the patients with parapsoriasis defined this way will never develop or manifest a diagnosable lymphoma [30]. Nevertheless, a proportion of patients with socalled parapsoriasis, for which, based on the available methods and in accordance with the existing criteria, one (still) cannot issue a diagnosis of mycosis fungoides, the malignant character will be seen later in evolution, due to disease progression [36].

Acknowledgment. This paper is supported by the Sectoral Operational Programme Human Resources Development (SOP HRD), financed from the European Social Fund and by the Romanian Government under the contract number POSDRU/159/1.5/S/137390.

Statement: The authors declare that there are no conflicts of interest.

\section{CONCLUSIONS}

A reliable diagnosis of mycosis fungoides in its early, but frequently manifested patch/plaque stage might be feasible only in conjunction with clinical, histopathological and molecular criteria. The detection of an epidermotropic $\mathrm{T}$ cell population is indeed typical, but not very specific for mycosis fungoides, being observed in many inflammatory dermatoses as well. Relatively specific criteria include epidermotropism without pronounced epidermal changes, the presence of Pautrier microabscesses, alignment of $\mathrm{T}$ lymphocytes along the basal layer of the epidermis, an abberant T-cell phenotype and the detection of a clonal T-cell population. In many cases, the disease will remain in a debatable clinical and histopathological diagnostic gray zone, often difficult to be accepted both by clinician and patient, the so-called parapsoriasis. In questionable cases, the histopathologist should not proffer a false diagnostic security, but rather discuss the ambiguity of the findings with the dermatologist. Often, the diagnosis will be clarified later in the course of the disease or after histopathologic evaluation of subsequent biopsies.

Mycosis fungoides este cel mai frecvent limfom cutanat primar cu celule T. In stadiile incipiente, afecțiunea este caracterizată printr-un tablou clinic şi histologic variabil, fiind dificil de diferențiat de anumite dermatoze inflamatorii. Deoarece nu există un criteriu de diagnostic suficient de specific pentru mycosis fungoides incipient, diagnosticul de certitudine în acest stadiu necesită interpretare integrată a modificărilor clinice, histopatologice şi moleculare. Cele mai utile modificări histologice pe biopsia cutanată sunt: prezența limfocitelor atipice în epiderm cu minime modificări epidermice secundare, alinierea limfocitelor de-a lungul stratului bazal al epidermului şi formarea de microabcese Pautrier. Un imunofenotip aberant şi detecția moleculară a unei populații clonale de celule $T$ sunt factori care ar putea facilita diagnosticul de certitudine. În această lucrare sunt recapitulați şi discutați din punct de vedere practic toți parametrii enunțați.

Corresponding author: Tiberiu Tebeică, MD

Dr Leventer Centre, Department of Histopathology

Sevastopol 13-17, Centrul Diplomat, Ste. 204

010991 Bucharest, Romania

Tel.: +4(021)3106507; Fax: +4(021)3106508

E-mail: tebeica@gmail.com

\section{REFERENCES}

1. BRADFORD PT, DEVESA SS, ANDERSON WF, TORO JR. Cutaneous lymphoma incidence patterns in the United States: a population-based study of 3884 cases. Blood. 2009; 113:5064-73.

2. PETERS MS, THIBODEAU SN, WHITE JW JR, WINKELMANN RK. Mycosis fungoides in children and adolescents. J Am Acad Dermatol. 1990; 22: 1011-18.

3. HWANG ST, JANIK JE, JAFFE ES, WILSON WH. Mycosis fungoides and Sezary syndrome. Lancet. 2008; 371:945-57. 
4. MASSONE C, KODAMA K, KERL H, CERRONI L. Histopathologic features of early (patch) lesions of mycosis fungoides: a morphologic study on 745 biopsy specimens from 427 patients. Am J Surg Pathol. 2005; 29:550-60.

5. SANTUCCI M, BIGGERI A, FELLER AC, BURG G. Accuracy, concordance and reproducibility of histologic diagnosis in cutaneous T-cell lymphoma. Arch Dermatol 2000; 136: 497.

6. PIMPINELLI N, OLSEN EA, SANTUCCI M, VONDERHEID E, HAEFFNER AC, STEVENS S, et al. Defining early mycosis fungoides. J Am Acad Dermatol 2005; 53:1053-63.

7. WILLEMZE R, JAFFE ES, BURG G, CERRONI L, BERTI E, SWERDLOW SH, et al. WHO-EORTC classification for cutaneous lymphomas. Blood. 2005; 105:3768-3785.

8. CERRONI L, FINK-PUCHES R, EL-SHABRAWI-CAELEN L, SOYER HP, LEBOIT PE, KERL H. Solitary skin lesions with histopathologic features of early mycosis fungoides. Am J Dermatopathol. 1999; 21:518-24.

9. SANTUCCI M, BIGGERI A, FELLER AC, MASSI D, BURG G. Efficacy of histologic criteria for diagnosing early mycosis fungoides: an EORTC cutaneous lymphoma study group investigation. European Organization for Research and Treatment of Cancer. Am J Surg Pathol. 2000; 24:40-50.

10. SMOLLER BR, BISHOP K, GLUSAC E, KIM YH, HENDRICKSON M. Reassessment of histologic parameters in the diagnosis of mycosis fungoides. Am. J. Surg. Pathol. 1995; 19:1423-1430.

11. STEVENS SR, KE MS, BIROL A, TERHUNE MH, PARRY EJ, ROSS C, et al. A simple clinical scoring system to improve the sensitivity and standardization of the diagnosis of mycosis fungoides type cutaneous T-cell lymphoma: logistic regression of clinical and laboratory data. Br J Dermatol. 2003; 149:513-22.

12. RALFKIAER E, CERRONI L, SANDER CA, SMOLLER BR, WILLEMZE R. Mycosis fungoides. In: Swerdlow SH, Campo E, Harris NL, Jaffe ES, Pileri SA, Stein H, Thiele J et al., editors. WHO classification of tumors of the haematopoietic and lymphoid tissues. IARC, Lyon, 2008.

13. SANCHEZ JL, ACKERMAN AB. The patch stage of mycosis fungoides: criteria for histologic diagnosis. Am J Dermatopathol. 1979;1:5-26.

14. NARAGHI ZS, SEIRAFI H, VALIKHANI M, FARNAGHI F, KAVUSI S, DOWLATI. Assessment of histologic criteria in the diagnosis of mycosis fungoides. Int J Dermatol. 2003;42: 45-52.

15. FREEMAN RG. Questions to the editorial board and other authorities [letter]. Am J Dermatopathol. 1986;8:536.

16. SUNDRAM UN. Epidermotropic reactions. In: Cualing HD, Kadin ME, Hoang MP, Morgan MB, editors. Cutaneous hematopathology - Approach to the diagnosis of atypical lymphoid-hematopoietic infiltrates in skin. Springer, New York, 2014.

17. DALTON SR, CHANDLER WM, ABUZEID M, HOSSLER EW, FERRINGER T, ELSTON DM, et al. Eosinophils in mycosis fungoides: an uncommon finding in the patch and plaque stages. Am J Dermatopathol. 2012; 34:586-91.

18. CITARELLA L, MASSONE C, KERL H, CERRONI L. Lichen sclerosus with histopathologic features simulating early mycosis fungoides. Am J Dermatopathol. 2003; 25(6):463-5.

19. CANDIAGO E, MAROCOLO D, MANGANONI MA, LEALI C, FACCHETTI F. Nonlymphoid intraepidermal mononuclear cell collections (pseudo-Pautrier abscesses). A morphologic and immunophenotypical characterization. Am J Dermatopathol. 2000; 22:1-6.

20. MICHIE SA, ABEL EA, HOPPE RT, WARNKE RA, WOOD GS. Discordant expression of antigens between intraepidermal and intradermal T cells in mycosis fungoides. Am J Pathol 1990; 137:1447-51.

21. WOOD GS, HONG SR, SASAKI DT, ABEL EA, HOPPE RT, WARNKE RA, et al. Leu-8/CD7 antigen expression by CD31 T cells: comparative analysis of skin and blood in mycosis fungoides/ Sezary syndrome relative to normal blood values. $\mathrm{J}$ Am Acad Dermatol 1990;22:602-7.

22. NUCKOLS JD, SHEA CR, HORENSTEIN MG, BURCHETTE JL, PRIETO VG. Quantitation of intraepidermal T-cell subsets in formalin-fixed, paraffin-embedded tissue helps in the diagnosis of mycosis fungoides. J Cutan Pathol 1999;26:169-75.

23. MASSONE C, CRISMAN G, KERL H, CERRONI L. The prognosis of early mycosis fungoides is not influenced by phenotype and T-cell clonality. Br J Dermatol. 2008; 159:881-6.

24. BURG G, DUMMER R, HAEFFNER AC, KEMPF W, KADIN M. From inflammation to neoplasia: mycosis fungoides evolves from reactive inflammatory conditions (lymphoid infiltrates) transforming into neoplastic plaques and tumors. Arch Dermatol 2001;137:949-52.

25. WOOD GS, HAEFFNER A, DUMMER R, CROOKS CF. Molecular biology techniques for the diagnosis of cutaneous T-cell lymphoma. Dermatol Clin 1994;12:231-41.

26. OLSEN EA, WHITTAKER S, KIM YH, DUVIC M, PRINCE HM, LESSIN SR, et al. Clinical end points and response criteria in mycosis fungoides and Sezary syndrome: a consensus statement of the International Society for Cutaneous Lymphomas, the United States Cutaneous Lymphoma Consortium, and the Cutaneous Lymphoma Task Force of the European Organisation for Research and Treatment of Cancer. J Clin Oncol. 2011; 29:2598-2607.

27. LANGERAK AW, GROENEN PJ, BRUGGEMANN M, BELDJORD K, BELLAN C, BONELLO L, et al. EuroClonality/ BIOMED-2 guidelines for interpretation and reporting of Ig/TCR clonality testing in suspected lymphoproliferations. Leukemia. 2012; 26:2159-71.

28. ZHANG B, BECK AH, TAUBE JM, KOHLER S, SEO K, ZWERNER J, et al. Combined use of PCR-based TCRG and TCRB clonality tests on paraffin-embedded skin tissue in the differential diagnosis of mycosis fungoides and inflammatory dermatoses. J Mol Diagn. 2010; 12:320-7.

29. KIKUCHI A, NAKA W, HARADA T, SAKURAOKA K, HARADA R, NISHIKAWA T. Parapsoriasis en plaques: its potential for progression to malignant lymphoma. J Am Acad Dermatol. 1993; 29(3):419-22. 
30. ACKERMAN AB. If small plaque (digitate) parapsoriasis is a cutaneous T-cell lymphoma, even an 'abortive' one, it must be mycosis fungoides! Arch Dermatol. 1996; 132:562-6.

31. SIMON M, FLAIG MJ, KIND P, SANDER CA, KAUDEWITZ P. Large plaque parapsoriasis: clinical and genotypic correlations. J Cutan Pathol. 2000; 27:57-60.

32. EL-DAROUTI MA, FAWZY MM, HEGAZY RA, ABDEL HAY RM. Hypopigmented parapsoriasis en plaque, a new, overlooked member of the parapsoriasis family: A report of 34 patients and a 7-year experience. J Am Acad Dermatol. 2012; 67:1182-8.

33. BURG G, DUMMER R, NESTLE FO, DOEBBELING U, HAEFFNER AC. Cutaneous lymphomas consist of a spectrum of nosologically different entities including mycosis fungoides and small plaque parapsoriasis. Arch Dermatol 1996;132:567-72.

34. BURG G, DUMMER R, HAEFFNER AC, KEMPF W, KADIN M. From inflammation to neoplasia: mycosis fungoides evolves from reactive inflammatory conditions (lymphoid infiltrates) transforming into neoplastic plaques and tumors. Arch Dermatol 2001;137:949-52.

35. WOOD GS, REIZNER GT. Small plaque parapsoriasis and large plaque parapsoriasis. In: Bolognia JL, Jorizzo JL, Schaffer JV, editors. Dermatology $3^{\text {rd }}$ ed. Elsevier, 2012.

36. WONG HK, MISHRA A, HAKE T, PORCU P. Evolving insights in the pathogenesis and therapy of cutaneous T-cell lymphoma (mycosis fungoides and Sezary syndrome). Br J Haematol. 2011; 155:150-66.

Received April 1, 2015 